\title{
Acetylator Status on Tuberculosis Patients Receiving Isoniazid-Contained Antituberculosis Regiment
}

\author{
I Gusti Ayu Artini, ${ }^{1}$ I Gusti Ngurah Bagus Artana ${ }^{2}$ \\ ${ }^{1}$ Pharmacology Department, Medical Faculty, Udayana University, Indonesia \\ ${ }^{2}$ Department of Internal Medicine, Medical Faculty, Udayana University, Indonesia
}

\begin{abstract}
Hepatotoxic incidence after tuberculosis treatment might reach 48\%. Isoniazid was the most important antituberculosis related to hepatotoxic effect. One of the important risk factor related to hepatotoxic is acetylator status that reflects the metabolism rate of isoniazid in the body. Slow acetylator was proven as significant risk factor of hepatotoxic effect after tuberculosis treatmment. The acetylator status is related to genetic variation on NAT2 gene, whereas genetic variation of NAT2 gene is strongly related to ethnic or race. This study aimed to study the acetylator status on tuberculosis patients receiving isoniazid-contained antituberculosis regiment. Acetylator status was analyzed from the NAT2 genotypes (NAT2 $* 5$, NAT2*6 and NAT2*7). Detection of NAT2*5, *6, and *7 genotypes was performed using PCR/RFLP technique. From 35 DNA samples isolated from tuberculosis patients receiving antituberculosis, as many as 8 subjects (22.9\%) and 27 subjects (77.1\%) were categorized as slow acetylator and rapid acetylator, respectively. The dominant acetylator status in tuberculosis patients was rapid acetylator.
\end{abstract}

Keywords: acetylator, NAT2, isoniazid

\section{Introductions}

The incidence of hepatotoxic effect after tuberculosis treatment was relatively high. It might reach $48 \%$ in several studies. Isoniazid is known to be antituberculosis that most responsible for the incidence of hepatotoxic. ${ }^{1,2}$

One of the contributing factor assumed to be related to this is the activity of antituberculosis-metabolizing enzyme, including $\mathrm{N}$-acetyl transferase 2 (NAT2). NAT2 enzyme is responsible for acetylation step of isoniazid metabolism. ${ }^{3,4,5,6,7,8,9}$

The activity of NAT2 (acetylator status) was strongly related to genetic variation on NAT2 gene. People with slow acetylator characteristic would have higher risk of hepatotoxic effect after tuberculosis treatment. Several studies had been studied about the relationship between acetylator status and risk of hepatotoxic; all of which showed a significant correlation. ${ }^{3,5,6,9,10,11,12}$

Otherwise, the proportions of slow acetylator were varies in several studies. Thus indicated the different risk for hepatotoxic effect in different population. As there wasn't any study yet regarding the acetylator status in tuberculosis patients in Indonesia, it become very important to studied about the acetylator status on tuberculosis patients receiving isoniazid-contained antituberculosis regiment.

\section{Methods}

This study was a cross sectional study. The samples of this study were taken from the DNA that had been isolated from tuberculosis patients who attended pulmonology outpatient clinic of Sanglah Hospital between June to December 2014. This study was approved by Ethical Committee of Sanglah Hospital. Acetylator status was analyzed from the NAT2 genotypes $(\mathrm{NAT} 2 * 5, \mathrm{NAT} 2 * 6$ and NAT $2 * 7)$. Detection of NAT $2 * 5, * 6$, and $* 7$ genotypes was performed using PCR/RFLP technique. The forward and reverse primers were 5'-GGA ACA AAT TGG ACT TGG-3' and 5'-TCT AGC ATG AAT CAC TCT GC-3', respectively. PCR was conducted on 35 cycles of reaction and the condition was set on:

\begin{tabular}{|c|c|c|}
\hline Step & Temperature (C) & Time (minutes) \\
\hline Initial denaturation & 94 & 5 \\
\hline Denaturation & 94 & 1 \\
\hline Annealing & 50 & 1 \\
\hline Extention & 72 & 1 \\
\hline Final extention & 72 & 10 \\
\hline
\end{tabular}

PCR products were restricted using KpnI, TaqI and BamHI restriction enzymes. Incubation was performed at $37^{\circ} \mathrm{C}$ for 90 minutes. The restriction products were visualized on $2 \%$ agarose gel. Acetylator status was categorized into 2 groups: slow and rapid acetylator. It was considered as slow acetylator if the NAT2 genotypes contained two mutant alleles; whereas rapid acetylator if the NAT2 genotypes contained one or two wild type alleles (NAT2*4).

\section{Results and Discussions}

Human NAT2 gene is located on chromosome 8 (8p22). ${ }^{10}$ The NAT2 $* 5, * 6$ and $* 7$ genotype patterns was shown on Table 1.

Table 1: NAT2 genotype pattern in tuberculosis patients

\begin{tabular}{|c|c|c|c|c|c|c|}
\hline Genotype pattern & \multicolumn{2}{|c|}{ NAT2 $* 5$} & \multicolumn{2}{c|}{ NAT2*6 } & \multicolumn{2}{c|}{ NAT2*7 } \\
\hline & $\mathrm{n}$ & $\%$ & $\mathrm{n}$ & $\%$ & $\mathrm{n}$ & $\%$ \\
\hline Wild type & 19 & 54.3 & 35 & 100 & 4 & 11.4 \\
\hline Mutant heterozygote & 13 & 37.1 & 0 & 0 & 25 & 71.4 \\
\hline Mutant homozygte & 3 & 8.6 & 0 & 0 & 6 & 17.2 \\
\hline
\end{tabular}




\section{International Journal of Science and Research (IJSR) \\ ISSN (Online): 2319-7064}

Index Copernicus Value (2015): 78.96 | Impact Factor (2015): 6.391

Based on the NAT2 genotype patterns, as many as 8 subjects $(22.9 \%)$ were categorized as slow acetylator whereas 27 subjects $(77.1 \%)$ were categorized as rapid acetylator. Slow acetylator was considered to be a significant risk factor related to hepatotoxic effect of antituberculosis. ${ }^{3,5,6,9,10,11,12}$ The acetylator status of tuberculosis patients based on subject characteristics were shown on Table 2.

Table 2: Acetylator status of tuberculosis patients based on subject characteristics

\begin{tabular}{|c|c|c|}
\hline Subject characteristics & $\begin{array}{c}\text { Rapid acetylator } \\
\mathrm{n}(\%)\end{array}$ & $\begin{array}{c}\text { Slow acetylator } \\
\mathrm{n}(\%)\end{array}$ \\
\hline Age & $13(81.3)$ & $3(18.8)$ \\
$-<30$ y.o & $14(14.7)$ & $5(4.3)$ \\
$-\geq 30$ y.o & $15(15.4)$ & $5(4.6)$ \\
\hline Gender & $12(11.6)$ & $3(3.4)$ \\
- Male & $18(16.2)$ & $3(4.8)$ \\
- Female & $9(10.8)$ & $5(3.2)$ \\
Initial BTA status & $7(5.4)$ & $0(1.6)$ \\
- Positive & $20(21.6)$ & $8(6.4)$ \\
- Negative & \multicolumn{2}{|l}{} \\
Other medication & Yes & \\
- No &
\end{tabular}

Isoniazid was considered to be antituberculosis that most responsible for the incidence of hepatotoxic effect after tuberculosis treatment. ${ }^{5,6}$ The first phase metabolism of isoniazid (acetylation process) is catalyzed by NAT2. The genetic variation on NAT2 gene might subsequently caused changes on NAT2 enzyme activity especially on isoniazid metabolism. Thus, it might affect the risk of hepatotoxic effect after tuberculosis treatment. ${ }^{10,13,14,15}$ The role of NAT2 in isoniazid metabolism can be seen on Figure 1.

Slow acetylator had been proven in many studies as a significant risk factor related to hepatotoxic effect of antituberculosis. This included several studies conducted in China, Japan, India, and Brazil. ${ }^{3,5,6,9,10,11,12}$

This study showed the major acetylator status in tuberculosis patients were rapid acetylator. This indicated that the risk of hepatotoxic effect after tuberculosis treatment in most of our subjects was relatively not high.

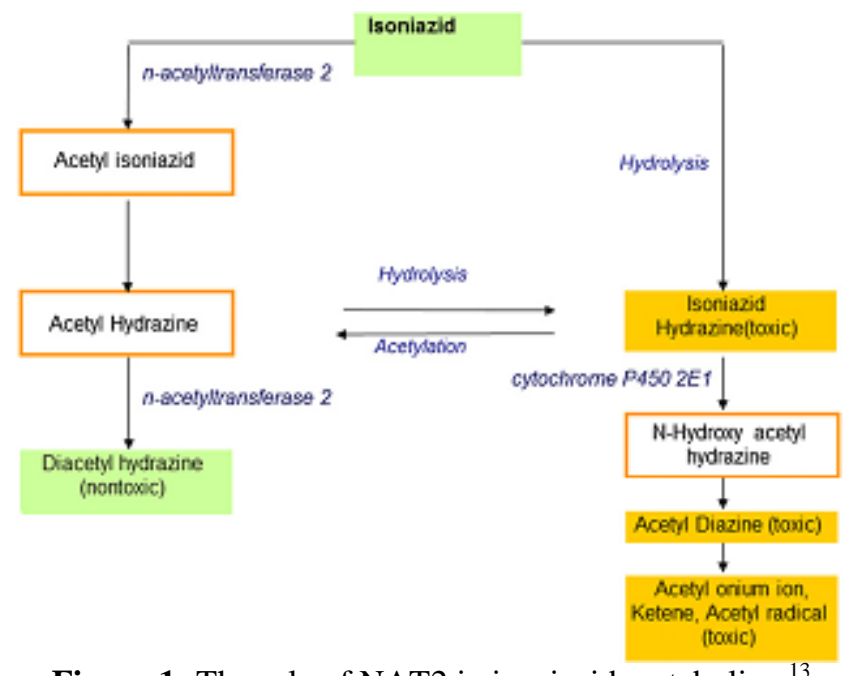

Figure 1: The role of NAT2 in isoniazid metabolism ${ }^{13}$
Compared to studies conducted in other countries, our result was similar to those in China and Japan. The proportion of rapid acetylator was also dominant in China $(71-80 \%)$ and Japan (91-94\%). ${ }^{4,5,9,10,11}$ Contrary to our result, the slow acetylator was dominant in several populations. The proportion of slow acetylator was slightly higher than rapid acetylator on studied conducted in India (55\%) and Brazil $(55 \%){ }^{3,16}$ This indicated the higher risk for hepatotoxic effect after tuberculosis treatment. This also proved that genetic variation was strongly related to the ethnicity or race.

\section{Conclusion}

The dominant acetylator status in tuberculosis patients was rapid acetylator.

\section{References}

[1] World Health Organization. Treatment of tuberculosis: Guidelines. $4^{\text {th }}$ edition. World Health Organization: Geneva. 2010.

[2] Wang T, Yu HT, Wang W, Pan YY, He LX, Wang ZY. Genetic polymorphisms of cytochrome p450 and glutathione s-transferase associated with antituberculosis drug-induced hepatotoxicity in Chinese tuberculosis patients. The Journal of International Medical Research. 2010. 38:977-986.

[3] Teixeira RLF, Morato RG, Cabello PH, Munizz LMK, Moreira ASR, Kritski AL, Mello FCQ, Suffys PN, deMiranda AB, Santos AR. 2011. Genetic polymorphisms of NAT2, CYP2E1 and GST enzymes and the occurrence of antituberculosis drug-induced hepatitis in Brazilian TB patients. Mem Inst Oswaldo Cruz. 106(6):716-724.

[4] Lv X, Tang S, Xia Y, Zhang Y, Wu S, Yang Z, Li X, Tu D, Chen Y, Deng P, Ma Y, Chen D, Chen R, Zhan S. NAT2 genetic polymorphisms and antituberculosis drug-induced hepatotoxicity in Chinese community population. Annals of Hepatology. 2012. 11(5):700-707.

[5] Huang YS, Chern HD, Su WJ, Wu JC, Lai SL, Yang SY, Chang FY, Lee SD. Polymorphism of the Nacetyltransferase 2 gene as a susceptibility risk factor for antituberculosis drug-induced hepatitis. Hepatology. 2002. 35:883-889.

[6] Cai Y, Yi JY, Zhou CH, Shen XZ. Pharmacogenetic study of drug-metabolizing enzyme polymorphism on the risk of antituberculosis drug-induced liver injury: a meta-analysis. Plos One. 2012. 7(10):e47769.

[7] Bose PD, Sarma MP, Medhi S, Das BC, Husain SA, Kar P. Role of polymorphic $\mathrm{N}$-acetyl transferase 2 and cytochrome P4502E1 gene in antituberculosis treatment-induced hepatitis. Journal of Gastroenterology and Hepatology. 2011. 26(2):312-318.

[8] Artini IGA, Artana IGNB. NAT2 genotype pattern among tuberculosis patients receiving fixed dose combination of antituberculosis. International Journal of Science and Research. 2016. 5(1):1-3.

[9] Lee SW, Chung LSC, Huang HH, Chuang TY, Liou YH, Wu LSH. NAT2 and CYP2E1 10. polymorphisms and susceptibility to first line antituberculosis druginduced hepatitis. International Journal of Tuberculosis and Lung Disease. 2010. 14(5):622-626.

\section{Volume 6 Issue 7, July 2017 www.ijsr.net}




\section{International Journal of Science and Research (IJSR) \\ ISSN (Online): 2319-7064}

Index Copernicus Value (2015): 78.96 | Impact Factor (2015): 6.391

[10] Fukino K, Sasaki Y, Hirai S, Nakmura T, Hashimoto M, Yamagishi F, Ueno K. Effect of N-acetyltransferase 2 (NAT2), CYP2E1 and glutathione s-transferase (GST) genotypes on the serum concentrations of isoniazid and metabolites in tuberculosis patients. The Journal of Toxicological Sciences. 2008. 33(2):187195.

[11] Hiratsuka M, Kishikawa Y, Takekuma Y, Matsuura M, Narahara K, Inoue T, Hamdy SI, Endo N, Goro J, Mizugaki M. 2002. Genotyping of the Nacetyltransferase 2 polymorphism in the prediction of adverse drug reaction to isoniazid in Japanese patients. Drug Metabolism and Pharmacokinetic. 17(4):357-362.

[12] Sun F, Chen Y, Xiang Y, Zhan S. Drug metabolizing enzyme polymorphisms and predisposition to antituberculosis drug-induced liver injury: a meta analysis. International Journal of Tuberculosis and Lung Disease. 2008. 12(9):994-1002.

[13] Ramappa V dan Aithal GP. Hepatotoxicity-related to antituberculosis drug: mechanism and management. Journal of Clinical and Experimental Hepatology. 2013; 3: 37-49.

[14] Caws M, Tho DQ, Duy PM, Lan NTN, Hoa DV, Torok ME, Chau TTH, Chau NVV, Chinh NT, FarrarJ. PCRrestriction fragment length polymorphism for rapid, low cost identification of isoniazid-resistant Mycobacterium tuberculosis. Journal of Clinical Microbiology. 2007. 45(6):1789-1793.

[15] Ramaswamy SV, Reich R, Dou SJ, Jasperse L, Pan X, Wanger a, Quitugua T, Graviss EA. Single nucleotide polymorphisms in genes associated with isoniazid resistance in Mycobacterium tuberculosis. Antimicrobial Agents and Chemotherapy. 2003. 47(4):1241-1250.

[16] Singh N, Dubey S, Chinnaraj S, Golani A, Maitra A. 2009. Study of NAT2 gene polymorphisms in an Indian population: association with plasma isoniazid concentration in a cohort of tuberculosis patients. Molecullar Diagnostic and Therapy. 13(1):49-58.

Volume 6 Issue 7, July 2017 www.ijsr.net 